\title{
KESEIMBANGAN DALAM PRODUKSI, DISTRIBUSI DAN KONSUMSI SEBAGAI UPAYA PEMBANGUNAN EKONOMI BERKELANJUTAN
}

\author{
Nandang Ihwanudin ${ }^{1)}$, Udin Saripudin ${ }^{2)}$, dan Suryani ${ }^{3)}$ \\ ${ }^{1,2)}$ Universitas Islam Bandung \\ ${ }^{3)}$ IAIN Lhokseumawe Aceh \\ E-mail: nandangihwanudin_mes@unisba.ac.id ${ }^{1)}$, \\ udin_saripudin27@yahoo.co.id ${ }^{2}$, , suryapijar@yahoo.com ${ }^{3)}$
}

\begin{abstract}
ABSTRAK
Penelitian ini dilatarbelakangi oleh perilaku manusiadalam memenuhi kebutuhannya. Mereka memenuhi kebutuhan konsumsi dengan melakukan upaya produksi dengan kemampuan mereka sendiri selagi mereka memiliki kemampuan untuk melakukannya. Apabila tidak mampu melakukannya, maka pemenuhan kebutuhan tersebut dipenuhi melalui distribusi dari hasil produksi pihak lain. Dalam upaya memenuhi kebutuhan atau bahkan keinginannya, manusia seringkali melakukannya melampaui batasan yang semestinya. Mereka melakukannya dengan melanggar keutuhan dan harmonisasi antara produsen, konsumen, dan distributor. Bahkan seringkali dalam upaya kegiatan ekonomi, mengganggu stabilitas dan keberlanjutan ekosistem. Penelitian ini bertujuan untuk merumuskan konsep keseimbangan dalam produksi, distribusi dan konsumsi sebagai upaya pembangunan ekonomi berkelanjutan. Metode yang digunakan adalah metode deskriptip analisis dengan studi dokumentasi. Hasil penelitian menemukan bahwa pembangunan ekonomi berkelanjutan dapat dicapai melalui keseimbangan para pelaku ekonomi dalam sektor produksi, distribusi dan konsumsi.
\end{abstract}

Kata kunci: keseimbangan, produksi, distribusi, konsumsi, ekonomi berkelanjutan. 


\begin{abstract}
This research is motivated by human behavior in meeting their needs. They meet consumption needs by making production efforts at their own capacity while they have the ability to do so. If unable to do so, then the fulfillment of these needs is met through distribution from the production of other parties. In an effort to meet their needs or even desires, humans often do it beyond their proper limits. They do this by violating the integrity and harmony between producers, consumers, and distributors. Even often in the efforts of economic activities, disrupting the stability and sustainability of ecosystems. This study aims to formulate the concept of balance in production, distribution and consumption as an effort to sustainable economic development. The method used is descriptive analysis method with documentation study. The results of the study found that sustainable economic development can be achieved through a balance of economic actors in the production, distribution and consumption sectors.
\end{abstract}

Keywords: balance, production, distribution, consumption, sustainable economy.

\title{
A. PENDAHULUAN
}

Keseimbanagan dalam ekobomi berpijak pada tiga kata kunci, yaitu: ${ }^{1}$ 1) Environmentally sustainable (pemeliharaan lingkungan). Didasarkan pada keyakinan bahwa biosfer kita adalah sistem tertutup dengan sumber daya terbatas dan kapasitas yang terbatas untuk pengaturan-diri dan pembaruan diri. manusia bergantung pada sumber daya alam di bumi, dan karena itu harus diciptakan suatu sistem ekonomi yang menghormati integritas ekosistem dan menjamin ketahanan sistem penyangga kehidupan. 2) Socially just (keadilan social), didasarkan pada keyakinan bahwa budaya dan martabat manusia adalah sumber daya yang berharga, seperti sumber daya alam, membutuhkan pelayanan yang bertanggung jawab untuk menghindari kekurangan masyarakat, harus menciptakan sistem ekonomi yang dinamis yang menjamin semua orang memiliki akses ke standar yang hidup yang layak dan penuh peluang

${ }^{1}$ Sumber: http://www.globalcitizencenter.org/_404_/diakses 27 Januari 2012 
untuk pengembangan pribadi dan sosial. 2) Locally rooted (berakar pada lingkungan sekitar), didasarkan pada keyakinan bahwa koneksi otentik ke tempat adalah kondisi sangat penting untuk keberlanjutan dan keadillan. Green Economy adalah agregat global setiap masyarakat dalm memenuhi kebutuhan warganya melalui produksi, dan bertanggung jawab terhadap lokalitas dan pertukaran barang dan jasa.

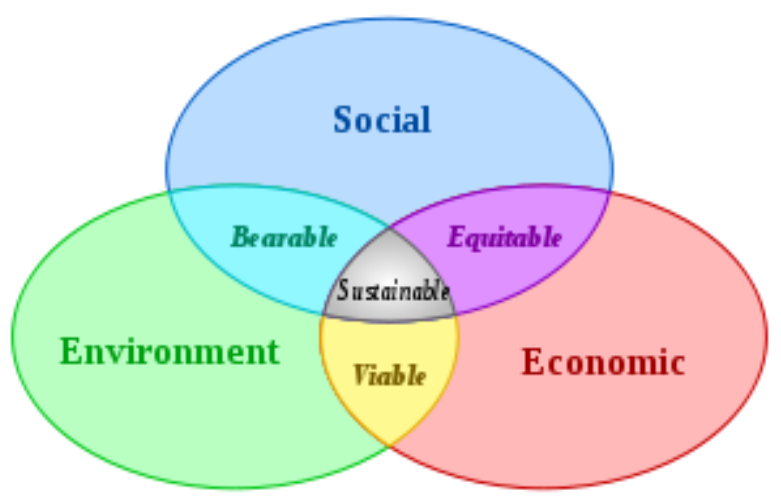

Berkaitan dengan hal di atas, Islam sebagai agama yang sempurna (kamilah), menyeluruh (syamilah), dan mencakup segala sesuatu, sejak empat belas abad yag lalu telah membicarakan isu ini meskipun dengan tendensi bahasa yang berbeda. Bahkan, Islam dalam kitab sucinya Al Quran mengisyaratkannya antara lain Allah Swt. berfirman:2"Dan kami Telah menghamparkan bumi dan menjadikan padanya gunung-gunung dan kami tumbuhkan padanya segala sesuatu menurut ukuran."

Semakin kukuh hubungan manusia dengan alam raya, semakin dalam pengenalan terhadapnya, akan semakin banyak manfaat yang diperoleh darinya. Hubungan yang sekedarnya bahkan cenderung tidak ada hubungan menimbulkan penindasan manusia atas manusia lainnya, atau terhadap alam itu sendiri. Hal ini ditegaskan Allah Swt. dalam firman-Nya, surat yang pertama kali turun, al-`Alaq (99) ayat 6-7; "Sesungguhnya mausia berlaku sewenag-wenang manakala dirinya merasa mampu." 3

\footnotetext{
${ }^{2}$ Q.S. 15: 19.

${ }^{3}$ M. Quraish Shihab, Membumikan Al-Quran (Bandung: Mizan. 1999), h. 296-297
} 
Indonesia sebagai negara berpenduduk muslim terbesar di dunia sedang berupaya mengimplementasikan konsep keseimbangan dalam pembangunan ekonomi, meskipun masih ada kebijakan yang belum sejalan dengan konsep tersebut, bahkan, meskipun dalam prakteknya UUD 1945 dijadikan rujukan, hal itu hanya sekedar untuk menyebut bahwa kebijakan-kebijakan ekonomi telah sesuai dengan UndangUndang Dasar Negara. ${ }^{4}$ Sementara itu, implementasi di lapangan antara kebijakan berupa perundang-undangan dengan aplikasinya masih terjadi kesenjangan, sebagaimana diindikasikan dengan kerusakan ekosistem dan ketidakadilan ekonomi di masyarakat masih sering terjadi, serta tidak seiramanya Pemerintah Pusat dan Pemerintah Daerah dalam mengeluarkan kebijakan pengelolaan Sumber Daya Alam. ${ }^{5}$

Bertitik tolak dari uraian di atas, penulis tertarik untuk melakukan penelitian tentang pembangunan ekonomi berkelanjutan yang ditandai dengan upaya keseimbangan dalam kegiatan ekonomi, yaitu dalam sektor produkssi, distribusi, dan konsumsi untuk mewujudkan pembangunan ekonomi berkelanjutan.

\section{B. TINJAUAN PUSTAKA}

\section{Etika dalam Produksi}

Yusuf Qardhawi salah satu pemikir ekonomi Islam terkemuka di dunia paling tidak membagi pembahasan terkait dengan norma produksi menjadi beberapa pembahasan yakni: Pertama, Peringatan Allah berkaitan dengan kekayaan Alam. Allah telah menciptakan kekayaan alam untuk manusia dengan berbagai macam jenis. Pertama, lapisan bumi dengan unsur yang berbeda-beda, berupa lapisan udara atau berbagai jenis gas. Kedua, lapisan kering, yang terdiri dari debu, bebatuan, dan barang tambang. Ketiga, lapisan air. Keempat, lapisan tumbuh-tumbuhan yang beraneka ragam yang terdiri dari ilalang dan hutan belukar. Juga kekayaan laut, baik yang terdapat di tepi pantai atau dilautan luas.

Kedua, Dalam memanfaatkan kekayaan alam, ilmu dan amal/kerja memegang peranan yang sangat penting. Al-qurân

\footnotetext{
${ }^{4}$ Jimli Assiddiqie, Konstitusi Ekonomi, (Jakarta: Penerbit Buku Kompas. 2010), h.

${ }^{5}$ Bencana kebakaran hutan di Sumatra dan Kalimantan salah satu faktanya.
} viii. 
menjelaskan bahwa memanfaatkan Sumber Daya Alam terfokus dalam dua hal. 1) ilmu atau sains yang berdiri diatas fondasi rasio dan akal budi. 2) Kerja. Bekerja dibutuhkan untuk menghasilkan sesuatu yang terbaik dan untuk mencapai karunia Allah. ${ }^{6}$ Islam sangat mengagungkan bekerja dan memasukkannya sebagai bagian dari ibadah. Disisi lain, pekerjaan dikategorikan sebagai jihad jika diniatkan dengan ikhlas dan diiringi dengan ketekunan dan ihsan. ${ }^{7}$

Ketiga, Pengaruh Ketenangan Jiwa dalam Berproduksi. Seorang mukmin akan menikmati kehidupan ini dengan ketenangan jiwa, kedamaian batin, dan kelapangan dada. Tidak diragukan, ketenangan jiwa seperti ini mempunyai dampak positif bagi produktivitas.

Keempat, Pengaruh Istiqamah dalam Berproduksi. Seorang muslim yang beriman selalu menjaga pola hidup, energi tubuh , kekuatan syaraf, daya tanggap otak dan rangsangan jiwanya. Ia tidak menggunakan kehidupan ini kecuali untuk melaksanakan pekerjanan yang bermanfaat atau menikmati hiburan halal.ini sekaligus keuntungan dan sekaligus modal bagi diri pribadi, istri, anak dan masyarakat sekitarnya.

Keempat, Nilai Waktu Bagi Seorang Muslim. Mukmin adalah manusia yang paling menghargai nilai waktu. ${ }^{8}$ Seoarng muslim takut apabila hari-hari berlalu tanpa melakukan pekerjaan dan aktivitas yang berarti. ${ }^{9}$ Ia tidak ingin pekerjaan pada hari ini diundur esok hari karena baginya diesok hari ada pekerjaan baru yang tidak bisa diusik. Seorang muslim mengharapkan hari ini lebih baik dari hari kemarin, dan esok lebih baik dari hari ini.

Kelima, Berproduksi Dalam Lingkaran Yang Halal. Prinsip etika dalam produksi yang wajib dilaksanakan oleh setiap muslim baik individu maupun komunitas adalah berpegang pada semua yang dihalalkan Allah dan tidak melampaui batas.

\footnotetext{
${ }^{6}$ Q.S. 62:10.

7 Agustianto memaparkan keutamaan bekerja dalam Islam sebabagai berikut: Bekerja Sendi Utama Produksi. Para ahli ekonomi menetapakan bahwa produksi terjadi lewat peranan tiga atau empat unsur yang saling berkaitan yaitu alam, modal, dan bekerja. Sebagian ahli lain menambahkan unsur disiplin.

${ }^{8}$ QS. 102 (al-`ashr): 1-3.

${ }^{9}$ QS. 59 (al-Hasyr):12.
} 
Keenam, Perlindungan Kekayaan Alam. Etika yang terpenting adalah menjaga sumber daya alam karena ia merupakan nikmat dari Allah kepada hambaNya. Setiap hamba wajib mensyukurinya dan slah satu cara mensyukuri nikmat adalah dengan menjaga sumber daya alam dari polusi, kehancuran, atau kerusakan. Allah berfirman: "Dan janganlah kamu membuat kerusakan dimuka bumi, sesudah Allah memperbaikinya."

Ketujuh, Perlindungan Kekayaan Alam. Ekonomi islam sangat menganjurkan silaksanakan aktivitas produksi dan mengembankanya, baik segi kualitas maupun kuantitas. Ekonomi islam tidak rela jika tenaga manusia atau komoditi terlantar begitu saja. Islam menghendaki semua tenaga dikerahkan untuk meningkatkan produktivitas lewat itqan (ketekunan) yang diridhai oleh Allah atas segala sesuatunya.

\section{Etika dalam distribusi}

Sistem ekonomi yang berbasis Islam menghendaki bahwa dalam hal pendistribusian harus berdasarkan dua sendi, yaitu sendi kebebasan dan keadilan kepemilikan. ${ }^{10}$ Kebebasan disini adalah kebebasan dalam bertindak yang di bingkai oleh nilai-nilai agama dan keadilan tidak seperti pemahaman kaum kapitalis yang menyatakannya sebagai tindakan membebaskan manusia untuk berbuat dan bertindak tanpa campur tangan pihak mana pun, tetapi sebagai keseimbangan antara individu dengan unsur materi dan spiritual yang dimilikinya, keseimbangan antara individu dan masyarakat serta antara suatu masyarakat dengan masyarakat lainnya. Keberadilan dalam pendistribusian ini tercermin dari larangan dalam al-qur'an antara lain dalam surat al-hasyr (59) ayat ke 7 yaitu agar supaya harta kekayaan tidak diperbolehkan menjadi barang dagangan yang hanya beredar diantara orang-orang kaya saja, akan tetapi diharapkan dapat memberi kontribusi kepada kesejahteraan masyarakat sebagai suatu keseluruhan ${ }^{11}$

${ }^{10}$ Yusuf Qardhawi, Norma dan Etika Ekonomi Islam, alih bahasa: Zainal Arifin, Lc dan Dra. Dahlia Husin, (Jakarta: Gema Insani Press, 2001)

11 Zainuddin Ahmad, Al-Qur'an: Kemiskinan dan Pemerataan Pendapatan, (Yogyakarta: Dana Bhakti Prima Yasa, 1998), hlm. 7 


\section{Etika dalam Konsumsi}

Al-Quran dan hadits memberikan petunjuk-petunjuk yang sangat jelas tentang konsumsi, membicarakan pola dan prinsip konsumsi lain surah al-A'raf ayat ke 31. "Hai anak Adam, pakailah pakaianmu yang indah di setiap (memasuki) mesjid, ${ }^{12}$ makan dan minumlah, dan janganlah berlebih-lebihan. ${ }^{13}$ Sesungguhnya Allah tidak menyukai orang-orang yang berlebih-lebihan".

Tujuan konsumsi dalam Islam adalah untuk mewujudkan maslahah duniawi dan ukhrawi. ${ }^{14}$ Maslahah duniawi ialah terpenuhinya kebutuhan dasar manusia, seperti makanan, minuman, pakaian, perumahan, kesehatan, pendidikan (akal). Kemaslahatan akhirat ialah terlaksananya kewajiban agama seperti shalat dan haji.

Selanjutnya yang harus diperhatikan bahwa segala sesuatu yang dikonsumsi haruslah halal dan thayyib. ${ }^{15}$ Selain itu, al-Quran mengingatkan agar manusia tidak hanyut dan tenggelam dalam kehidupan yang materialistis dan hedonistis. Akan tetapi hal itu bukan berarti, bahwa Islam melarang manusia untuk menikmati kehidupan dunia ini. Sebagai anugerah Allah.

Dengan demikian, prinsip akhlak islami mengajarkan bahwa konsumsi harus dapat memenuhi etika, adat kesopanan dan perilaku terpuji seperti syukur, zikir, dan fikir serta sabar dan mengesampingkan sifat-sifat tercela seperti kikir dan rakus. ${ }^{16}$

\section{METODOLOGI PENELITIAN}

\section{Metode Penelitian}

Dalam penyusuan penelitian ini, digunakan metode penelitian kualitatif, yaitu suatu penelitian yang hanya menggambarkan keadaan dari obyek yang diteliti berkaitan dengan objek yang dibahas dalam

\footnotetext{
${ }^{12}$ Maksudnya: tiap-tiap akan mengerjakan sembahyang atau thawaf keliling ka'bah atau ibadat-ibadat yang lain.

${ }^{13}$ Maksudnya: janganlah melampaui batas yang dibutuhkan oleh tubuh dan jangan pula melampaui batas-batas makanan yang dihalalkan.

${ }^{15}$ Lihat firman Allah dalam surah Al-Baqarah : 168 dan Al-A'raf : 157. ${ }^{16}$ Q.S. 89 (Al-Fajr):20, 70 (al-Ma ārij):19
} 
penelitian. ${ }^{17}$ Metode ini digunakan untuk meneliti kondisi objek yang alamiah, dimana peneliti merupakan instrument kunci. ${ }^{18}$

Selanjutnya, penulis tidak hanya menyusun data saja akan tetapi mengembangkannya dengan memberikan penafsiran (interpretasi) yang memadai terhadap fakta-fakta yang ditemukan, interpretasi data itu sendiri akan mengambil jenis analisis isi (content analysis) karena jenis ini merupakan bagian dari bentuk survei ( survey studies) dalam penelitian deskriptif. ${ }^{19}$ Menurut Krippendorff, analisis isi adalah teknik penelitian yang dimanfaatkan untuk menarik kesimpulan yang replikatif dan sahih dari data atas dasar konteksnya. ${ }^{20}$

\section{Sumber Data}

Sumber data ${ }^{21}$ primer meliputi kajian Ayat-ayat Al- Quran, Hadits-hadits Nabi, buku-buku Tafsir yang berkaitan dengan produksi, distribusi dan konsumsi dan buku-buku serta dokumen dari para pemangku kebijakan terkait langsung dengan obyek penelitian ini. Data yang digunakan merupakan data sekunder yang diperoleh dari buku-buku, dokumen-dokumen, internet dan media informasi yang menunjang serta hasil penelitian lain yang ada kaitannya dengan penelitian ini.

\section{Teknik Pengumpulan Data}

Dalam penelitian ini, pengumpulan data dilakukan dengan teknik dokumentasi dan studi pustaka. Penulis akan melakukan kajian terhadap ayat-ayat Al-Quran dan Hadits-hadits nabi dengan pendekatan tafsir maudhu iy, ${ }^{22}$ meneliti literatur-literatur klasik dan

${ }^{17}$ Suharsimi Arikunto, Prosedur Penelitian Suatu Pendekatan Praktek, ed. Revisi, cet. 12, (Jakarta: Rineka Cipta, 2002), h. 21

18 Sugiyono, Metode Penelitian Kuantitatif, kualitatif dan $R \& D$ (Bandung: Alfabeta. 2006), hlm. 9

${ }^{19}$ Hadari Namawi h. 68

${ }^{20}$ Lexy J. Moloeng h.163

${ }^{21}$ Iqbal Hasan, Pokok-Pokok Materi Metodologi Penelitian dan Aplikasinya, (Jakarta: Gralia Indonesia, 2002), h. 82

${ }^{22}$ Menurut Abdul Hayy al-Farmawi, Tafsir maudhu i adalah tafsir al-quran yang tidak didasarkan pada urutan ayat demi ayat, namun para mufasir memulai kajiannya dari realitas kehidupan manusia, atau dari tema-tema tertentu sambil mengutip hadits-hadits tertentu maupun keterangan-keterangan lainnya yang relevan dengan masalahnya dan membantu pemecahannya. Abdul Hayy al-Farmawi, al-bidayah fi tafsir al-maudhu'I; dirosah manhajiyyah maudhu'iyyah, terj. Suryan a. jamroh, (Jakarta: raja grafindo,1994, h. 11) 
kontemporer yang berkaitan dengan keseimbangan produksi, distribusi, dan konsumi dalam upaya mewujudkan keseimbangan dalam pembangunan ekonomi.

\section{Rumusan Analisis Data}

Analisis data dilakukan dengan cara analisis deskripsi dari sebuah fenomena yang terjadi. dalam kontek penelitian ini, ingin ditemukan bagaimanakah konsep keseimbangan dalam kegiatan ekonomi yang dapat mewujudkan kesejahteraan sosial dan terpeliharanya kelestarian lingkungan.

\section{HASIL PENELITIAN DAN PEMBAHASAN \\ 1. Keseimbangan dalam produksi persfektif Islam}

Persoalan utama dalam perekonomian adalah bagaimana menjawab problem kelangkaan sebagai akibat ketidakseimbangan antara kebutuhan masyarakat dengan faktor-faktor produksi yang tersedia ${ }^{23}$ (sumber daya, modal, tenaga kerja dan manajemen). Kebutuhan dasar manusia terbentang dari kebutuhan yang sifatnya individual (private goods) seperti sandang, pangan dan papan, dan kebutuhan publik (public goods) seperti pendidikan, kesehatan dan ilmu pengetahuan dan teknologi. Dua bentuk kebutuhan tersebut merupakan sarana kehidupan yang tak terelakkan. Untuk memastikan keseimbangan dua kebutuhan tersebut, penggunaan dan penguasaan serta faktor-faktor produksi, serta proses produksi harus berada dalam kerangka keadilan.

Sumber daya alam adalah sarana utama dalam produksi guna memenuhi kebutuhan dasar manusia yang sifatnya universal. ${ }^{24} \mathrm{Al}-$ Qur'an secara meyakinkan percaya bahwa sumber daya itu tersedia dalam kadar yang "cukup" untuk memenuhi kebutuhan umat manusia. Pandangan al-Qur'an tentang sumber daya berbeda dengan keyakinan dari Prinsip Libertarian dan Rawlsian yang percaya bahwa sumber daya alam itu tidak terbatas dan karenanya tidak penting untuk dipertimbangkan dalam faktor pembangunan dan pendapatan nasional. Dua faktor yang menentukan pembangunan dan pendapatan

${ }^{23}$ P3EI, Ekonomi Islam, h. 7

${ }^{24}$ QS. 14 (Ibrāhìm): 32-33; 16: 10-11, 66-67; 57: 25 
nasional adalah sumber daya manusia atau tenaga kerja dan modal. Sementara itu, Prinsip Rawls yang menjadi dasar bagi welfare state meyakini sumber daya itu barang langka, namun tetap tidak diperhitungkan dalam faktor-faktor pembangunan dan pendapatan nasional. Dengan demikian, dua prinsip di atas pada hakikatnya samasama tidak menaruh kepedulian atas faktor sumber daya sebagai bagian penting dalam menentukan kelanjutan pembangunan dan pendapatan nasional.

Al-Qur'an juga mengenal konsep tentang modal, yakni segala sesuatu yang melibatkan campur tangan manusia (kerja, man made) dan penggunaan sumber daya alam dalam proses produksi. Secara kategoris bahwa kekayaan hasil tangan manusia sebagai modal dapat dibedakan secara bertingkat menjadi tiga tingkatan: Al-Rizq: kekayaan/modal sebagai faktor produksi yang masih mungkin di dalamnya terdapat unsur atau cara memperoleh yang halal dan atau haram; Al-Fadhl: kekayaan/modal sebagai faktor produksi yang diusahakan melalui cara-cara yang halal, inilah yang disebut sebagai "modal bebas korup"; dan ath-Thayyibah: kekayaan/modal sebagai faktor produksi yang memiliki 3 indikator: Dari segi substansinya ia tidak bercampur antara yang halal dan haram, tidak membahayakan jiwa dan akal, dan banyak manfaatnya. Dari segi cara memperolehnya halal. Dari segi dampaknya, ia peduli pada kelestarian lingkungan, menjamin kelangsungan keanekaragaman hayati, swasembada pangan, bebas polusi udara dan air, dan sanitasi lingkungan. Inilah yang disebut sebagai "modal bebas korup dan ramah lingkungan".

Tiga hierarki modal di muka, memperkuat prinsip al-Qur'an tentang pendayagunaan sumber daya alam dan lingkungan yang tidak dikenal dalam prinsip keadilan manapun. Campur tangan manusia atas sumber daya sebagai faktor produksi perlu memperhitungkan secara cermat ketersediaannya secara lestari. Karena itu, modal sebagai intervensi manusia yang juga merupakan faktor produksi mesti memasukkan pertimbangan cara-cara intervensi yang benar dan memiliki dampak positif bagi lingkungan.

Ketersediaan sumber daya alam tidak ada manfaatnya bila manusia sendiri tidak produktif. Sumber daya alam akan memberikan 
kegunaan dengan daya dukung aktivitas produksi. Islam mengandaikan berbagai macam aktivitas ekonomi seperti pertanian, peternakan, perdagangan, industri, dan pekerjaan dalam berbagai profesi. Secara eksplisit al-Qur'an menyebutkan istilah kerja dengan kasb. ${ }^{25}$ Pekerja akan produktif jika ia memiliki etos kerja yang tercermin dalam ikhtiar, ${ }^{26}$ yakni kebebasan manusia untuk menentukan nasib dirinya sendiri. Al-Qur'an, kemudian, menegaskan bahwa manusia hidup untuk bekerja sebagai konsekuensi dari kedudukannya sebagai pemakmur dunia. Konsekwensinya tiada jalan yang lebih baik untuk memenuhi fungsi kekhalifahan ini melainkan berbuat ihsan, mengisi waktu dengan kerja profesional dan aktivitas produktif. ${ }^{27}$ Profesionalisme dan produktivitas kerja manusia juga dipengaruhi oleh motivasi intrinsik. Untuk mencapai suatu kehidupan sosial-ekonomi yang berkeadilan diperlukan motivasi individu yang benar sebagai suatu mekanisme filter yang baik.

Prinsip al-Qur'an secara tegas mengasumsikan bahwa kepentingan pribadi tidak selalu merupakan motivasi yang buruk. Kepentingan pribadi akan berbahaya bagi masyarakat jika melampaui batas-batas kemanusiaan dan tidak diarahkan untuk menciptakan suatu masyarakat yang menjadikan persaudaraan dan keadilan sosioekonomi sebagai tujuan utamanya. Ada mekanisme yang efektif di sini dan perlu diciptakan untuk mendorong individu agar bekerja demi kepentingan masyarakat, sembari mengakui bahwa kepentingan pribadi adalah suatu keniscayaan. Keseimbangan antara dua kepentingan ini digariskan oleh al-Qur'an melalui prinsip tolongmenolong dalam kebajikan dan takwa (ta`awun ‘ala al-birr wa attaqwa). ${ }^{28}$

Sebagai akibat perbedaan etos kerja, bakat bawaan dan ketrampilan yang diajarkan, "perbedaan" pada prinsipnya merupakan keniscayaan dan hakikat dari kehidupan alamiah yang tak bisa ditolak. Perbedaan merupakan pijakan nyata untuk menciptakan

\footnotetext{
${ }^{25}$ QS. $4($ an-Nisā'):32.

${ }^{26}$ QS. $13\left(\operatorname{ar}-R a^{\prime} d\right): 11$.

${ }^{27}$ QS. $103($ al- 'Ashr $): 1-3$.

${ }^{28}$ QS. 5 (al-Mā'idah): 3.
} 
keseimbangan ekonomi. Kaya dan miskin, majikan dan buruh, pemilik dan penggarap tanah, atasan dan bawahan, adalah dua status dan fungsi dalam relasi ekonomi "kemitraan", yakni suatu relasi kerjasama dan partisipasi, saling memanfaatkan untuk keuntungan bersama, ${ }^{29}$ bukan hubungan atas-bawah yang berbingkai eksploitasi dan opresif.

Hubungan antara tenaga kerja dan modal selalu mewarnai kegiatan ekonomi. Hubungan keduanya sering menimbulkan konflik yang menimbulkan dampak buruk yang rumit. Persoalan ini bersumber dari kenyataan bahwa kepemilikan dan penguasaan modal hanya menjadi hak bagi kapitalis. Sementara tenaga kerja tidak berpatisipasi dalam proses penguasaan faktor-faktor produksi. Tenaga kerja sebagai bagian dari faktor produksi tidak dihitung sebagai penyertaan modal oleh kaum Kapitalis. Karenanya eksploitasi tidak dapat terelakkan.

Al-Qur'an mencoba memberikan solusi atas konflik industri berbasis relasi tenaga kerja dan modal melalui prinsip kemitraan yang termanifestasi dalam dua bentuk kerjasama, yakni musyarakah dan mudharabah. Dua bentuk kerjasama ini pada dasarnya merupakan cerminan dan manifestasi dari prinsip keadilan ( $a d l$ ), altruisme (ihsan) dan meritokrasi (nasib). ${ }^{30}$

Keadilan juga harus menjadi kerangka proses produksi. Oleh karena kebutuhan harus terus tersedia sepanjang masa, proses produksi perlu mempertimbangkan faktor-faktor non-ekonomi, utamanya kelestarian sumber daya alam yang dapat menjamin kesinambungan spesies manusia dan non-manusia. Ekologi, dengan demikian, perlu berada di dalam kalkulasi aktivitas produksi, dan aktivitas ekonomi pada umumnya. Rasionalitas ini menyadarkan bahwa efisiensi dalam aktivitas produksi adalah terbatas dan bergantung kepada kondisi-kondisi yang berada di luar ekonomi itu sendiri.

Karena itu, al-Qur'an menegaskan relasi yang seimbang (tawazun) antara manusia dan alam. Alam bukanlah proyek

${ }^{29}$ QS. 43 (az-zukhrūf): 32.

${ }^{30}$ Q.S. 16 (an-Nahl): 90, 4 (an-Nisa) ) 32. 
promothean (seperti prinsip Libertarian), yang menjadi "objek" bagi manusia; ${ }^{31}$ Bumi ini diciptakan menjadi hak bagi semua komunitas makhluk yang ada di dalamnya. ${ }^{32}$ Mempertimbangkan sumber daya alam dan lingkungan serta hak-hak ekologis dari spesies di luar manusia, proses produksi yang melibatkan teknologi perlu memperhatikan kelestarian dan mempertahankan keseimbangan ekologis yang dibutuhkan untuk kehidupan dan memihak kepada perkembangan dan otonomi dari individu-individu dan komunitaskomunitas yang bersifat ramah lingkungan. Al-Qur'an menyebutnya dengan ungkapan "bersyukur", agar negeri yang damai dan sejahtera, baldah thayyibah, ${ }^{33}$ dapat menjadi kenyataan.

\section{Keseimbangan dalam distribusi persfektif Islam}

Distribusi $^{34}$ sebagaimana dirujuk oleh istilah dulah ${ }^{35}$ dalam alQur'an merupakan landasan pentingnya peradaran harta, kekayaan dan pendapatan agar tidak terkonsentrasi di tangan orang-orang tertentu yang sudah kaya atau berkecukupan secara ekonomi. ${ }^{36} \mathrm{Di}$ samping pernyataan langsung tentang perlunya pendapatan dan kekayaan didistribusikan sehingga tidak terjadi konsentrasi, alQur'an juga menyebutkan tiga macam tindakan yang mencegah terjadinya proses distribusi yang adil, yakni larangan menimbun harta (al-iktināz), ${ }^{37}$ bermegah-megahan yang melalaikan (al-takätstsur), ${ }^{38}$ dan celaan atas penumpukan harta dan terlalu "perhitungan" (jama`a $m \bar{a} l$ wa 'addadah). ${ }^{39}$ Dilarang pula praktik monopoli. ${ }^{40}$

Untuk menjalankan proses distribusi dibutuhkan basis legitimasi. Yang dimaksud basis adalah kriteria atau prinsip apa pun yang

${ }^{31}$ Q.S. 6 (al-An'ām):38.

${ }^{32}$ Q.S. 55 (ar-Rahmān):10,

${ }^{33}$ Q.S. 34 (Saba'): 15.

${ }^{34}$ P3EI, h. 10. Distribusi adalah bagaimana sumber daya dan komomditas didistribusikan di masyarakat agar setiap individu dapat mencapai mashlahah.

${ }^{35}$ QS. 59 (al-Hasyr)): 7.

${ }^{36}$ QS. 59(al-Hasyr)): 7.

${ }^{37}$ Ibnu Manzur, Lisan al- Arab, vol. 5, hlm.401-402.

${ }^{38}$ QS. 102:1.

${ }^{39}$ QS. 104:1-2.

${ }^{40}$ Lihat Hadits riwayat Imam Muslim dalam buku Imam al-Mundzir, h. 94. Lihat pula M. Syafili Antonio, Bank Syariah: Dari Teori ke Praktek, (Jakarta: Gema Insani. 2001), h. 15 
menentukan dan berlaku bagi siapa saja yang memiliki hubungan nyata dengan kekayaan dan pendapatan. Kriteria distribusi yang memungkinkan cukup banyak dan inilah yang menyebabkan perbedaan natural atau perbedaan perolehan antara individu-individu. Kriteria itu meliputi: pertukaran, ${ }^{41}$ kebutuhan, ${ }^{42}$ kekuasaan, ${ }^{43}$ dan sistem sosial atau nilai etis atau akhlak.

Skema distribusi perlu didefinisikan melalui sejumlah ukuran dan kebijakan distribusi yang dipandu oleh aturan-aturan syariah dengan seluruh implikasi ekonominya. Skema distribusi itu sendiri meliputi dua macam: Pertama, distribusi pra produksi atas sumber daya atau kekayaan alam, antara lain: 1) kemitraan untuk mengatasi kesenjangan antarindividu yang diakibatkan oleh perbedaan kuantitas aset produktif ${ }^{44}$ baik berupa kepentingan publik dan beberapa jenis sumber daya alam; 2) larangan membatasi akses ekonom karena bertentangan dengan prinsip kemitraan atas manfaat kekayaan alam dari tanah yang tidak bertuan; 3) merampas tanah yang tidak produktif untuk tujuan produktif melalui mekanisme iqtha; 4) regulasi barang tambang untuk kesejahteraan publik; 5) efisiensi sumber daya air dan sumber daya alam terbarukan. Kedua, regulasi distribusi output produksi (kekayaan dan pendapatan) yang diambil dari harta orang kaya dan sumber pendapatan lainnya, untuk kemudian dikumpulkan di Baitul mal, lalu didistribusikan kepada orang yang membutuhkan ${ }^{45}$, yaitu antara lain: 1) berbagi surplus pemanfaatan modal produksi; 2) warisan untuk pemerataan kekayaan $^{46}$; 3) zakat sebagai wujud solidaritas sosial ${ }^{47}$;4) wakaf

${ }^{41}$ QS. 2 (AL-Baqarah) :275.

${ }^{42}$ QS. 11 (Hūd):6.

${ }^{43}$ QS. 11( Hūd)::3.

${ }^{44}$ QS. 43 (Saba'): 32.

${ }^{45}$ Dalam hal ini, Negara/khlifah berkewajiban menjaga economic equilibrium. An-Nabhani, An-Nizdzam al-Iqtishadi fi al-Islam. h. 274.

${ }^{46}$ QS. 4 (an-Nisā'):7, lihat juga ayat 8-14.

${ }^{47}$ QS. 9 (at-Taubah) :60. 
sebagai filantropi $\operatorname{sosial}^{48}$; 5) hadiah tanpa pamrih 6) al-fay, ${ }^{49}$ alghanimah dan rikaz untuk kesejahteraan bersama.

Memberikan surplus pemanfaatan modal berupa aset-aset tetap memperkuat penolakan al-Qur'an terhadap Prinsip Berbasis Balasan yang mengharuskan adanya kompensasi terhadap apa pun dalam aktivitas produksi, termasuk di dalamnya surplus modal harus diganti dengan biaya bagi mereka yang ingin mempergunakannya. Sistem warisan kekayaan memberikan argumen atas penolakan al-Qur'an terhadap pernyataan Prinsip Berbasis Balasan bahwa setiap orang harus menerima balasan sesuai dengan kontribusi aktualnya. Warisan mendistribusikan dan mentransfer kekayaan dari orang meninggal kepada anggota keluarganya yang berhak tanpa memandang apakah anggota keluarga itu memberi kontribusi atau tidak atas kekayaan orang meninggal.

Distribusi zakat merupakan bantahan atas Prinsip Libertarian Nozick yang menyatakan bahwa pajak apa pun atas pendapatan dan kekayaan (dan pungutan semisalnya termasuk zakat) oleh negara merupakan pelanggaran atas hak-hak kepemilikan eksklusif (selfinterest) karena membiarkan orang untuk memiliki sebagian hak orang lain; pajak dapat dikatakan sama dengan kerja paksa; tidak adil seseorang bekerja untuk kepentingan orang lain. Di sisi lain, tampak jelas bahwa praktek zakat merupakan bantahan atas Prinsip Berbasis Balasan tentang "kontribusi aktual". Pengeluaran zakat dari kepemilikan pribadi adalah sah dan penerima zakat juga sah memperoleh sekaligus memiliki bagian itu tanpa memandang kontibusi aktualnya.

Berbeda dengan Prinsip Berbasis Kesejahteraan atau Utilitarianisme yang berupaya memaksimalkan kesejahteraan masyarakat dengan mengorbankan sekelompok kecil lainnya, institusi wakaf bekerja dengan logika kepentingan publik (almaslahah al-`ammah). Artinya, demi kepentingan publik, individu

${ }^{48}$ QS. 3 (Ali 'Imrān):92.

${ }^{49}$ QS. 59(al-Hasyr) ; 6 ; lihat juga pada ayat-ayat 7-10, yang menyebutkan bagian harta ini untuk Allah dan rasul-Nya, kaum kerabat, anak yatim, orang miskin, ibnu sabil, orang fakir yang berhijrah dan terusir dari kampung halamannya. 
diperkenankan mewakafkan harta/kekayaannya dengan pengorbanan tulus. Dengan kata lain, individu berkorban demi kesejahteraan masyarakat, bukan sebaliknya atas nama kesejahteraan masyarakat kepentingan individu atau kelompok kecil dikorbankan.

Sedangkan skema distribusi pendukung meliputi: larangan atas riba sebagai eksploitasi terhadap mereka yang lemah ${ }^{50}$; larangan atas penimbunan harta; dan larangan atas monopoli. ${ }^{51}$

Secara jelas al-Qur'an menunjukkan keberpihakan terhadap orang-orang miskin dan tertindas. Populasi kaum mustadh ‘afin baru yang merupakan produk dari kecenderungan politik dan ekonomi struktural selama tiga dekade terakhir, akan terus tumbuh dan meningkat lebih-lebih setelah periode krisis ekonomi yang meluas. Keadaan semacam ini membuat populasi mereka akan menjadi subkultur yang menyebar mulai dari krisis perumahan dan pekerjaan, penyusutan besar dalam belanja sosial, perubahan-perubahan pada level makro ekonomi, strategi pembangunan kembali potensi lokal, dan sejumlah sebab-sebab lain.

Oleh karena itu, problem kemiskinan dan ketertindasan saat ini lebih mencerminkan kemiskinan, pemiskinan dan penindasan "struktural". Maka, diperlukan proses redistribusi secara sistemik ${ }^{52}$ untuk dapat mengangkat derajat mereka yang kurang beruntung dari ketidakberdayaan, ketidakpastian dan kelangkaan, karena di sinilah permasalah ekonomi yang sesungguhnya. Bukan terletak pada keterbatasan sumber daya ${ }^{53}$. Merujuk kepada al-Qur'an surat al-Anfal ayat 26, upaya-upaya keberpihakan terhadap eksistensi mereka dapat meliputi dua hal; layanan sosial-karitatif dan pemberdayaan sosial. Yang pertama bertujuan untuk memenuhi kebutuhan dasar mereka agar tetap survival; yang kedua bermaksud untuk mengangkat "kapasitas" dan "otoritas" mustad afin agar sustainable. ${ }^{54}$

${ }^{50}$ QS.3 (Ali 'Imrān): 130; lihat juga 30 (ar-Rēm):39.

${ }^{51}$ Lihat al-Mundziri, Hadits Muslim hal 94.

${ }^{52}$ Annabhani, An-Nidzam al-Iqtisadi fi al-Islam, terj. H 271.

${ }^{53}$ Annabhani, An-Nidzam al-Iqtisadi fi al-Islam, terj. H. 20-21

${ }^{54}$ M. Syafi' I Antonio, Bank Syariah: Dari Teori ke Praktek, (Jakarta: Gema Insani. 2001), h. 16. 
"Peningkatan kapasitas" berupa membuka akses atau peluang bagi mereka untuk memperoleh pendidikan, pelayanan kesehatan dan ketrampilan (life skill) sehingga tidak lagi menjadi orang yang lemah fisik maupun mental (Pro Poor) $)^{55}$. Pendidikan yang murah, peningkatan ketrampilan dan akses pelayanan kesehatan yang mudah mendorong terjadinya peningkatan kualitas hidup. Potensi mereka dapat dikembangkan dengan cara meningkatkan keterampilan hidupnya (life skills). Cara ini akan menyebabkan kaum mustadh ‘afin memiliki posisi tawar yang lebih baik dan diharapkan dapat meningkatkan derajat kelayakan hidup secara memadai dengan mendapatkan peluang pekerjaan (pro jobs). 56 "Peningkatan otoritas" kaum mustadh 'afin dalam proses pengambilan keputusan. Terpenuhinya kebutuhan-kebutuhan dasar (sandang, pangan, papan), terbukanya akses dan peluang pendidikan dan ketrampilan, serta pelayanan kesehatan yang murah dan mudah memang penting.

Keberpihakan itu pada akhirnya mesti memasuki wilayah politik. Alangkah makin mantap jika pemberdayaan sosial juga mencakup pelibatan kaum tertindas dan miskin itu sebagai bagian dari warga negara dalam posisi menentukan kebutuhan dan kepentingan mereka, memutuskan kebijakan secara bersama-sama dengan kelompok sosial lainnya. Sesudah partisipasi dapat diraih, usaha berikutnya adalah memposisikan kaum mustadh 'afin sebagai pengawas terhadap pelaksanaan kebijakan-kebijakan atau keputusan penting bagi mereka. Partisipasi dalam pengambilan keputusan saja belum cukup. Melakukan kontrol (controling) atas bagaimana implementasi kebijakan itu berjalan memungkinkan mereka dapat menjaga dan memelihara kepentingan-kepentingan sosial-ekonomi mereka. Partisipasi dan kontrol membuat mereka memiliki otoritas dan kekuatan di hadapan kelompok-kelompok sosial lainnya.

\footnotetext{
${ }^{55}$ Soeharsono Sagir, h. 51

${ }^{56}$ Ibid, h. 51
} 


\section{Keseimbangan dalam konsumsi persfektif Islam}

Produks $^{57}$ dan konsumsi ${ }^{58}$ adalah dua aspek ekonomi yang berpasangan. Dalam ilmu ekonomi, konsumsi adalah permintaan (demand), sedangkan produksi adalah penawaran (supply). Konsumsi adalah tahapan terakhir dan terpenting dalam produksi kekayaan. Konsumsi merupakan tujuan dari semua aktivitas produksi. Kekayaan diproduksi hanya untuk dikonsumsi. Kekayaan yang diproduksi sekarang akan dikonsumsi besok.

Konsep tentang konsumsi dalam al-Qur'an tersurat dalam ungkapan infaq. Kata ini dalam berbagai bentuknya tersebut sebanyak 71 kali dalam al-Qur'an. Infaq adalah suatu tindakan membelanjakan harta untuk kepentingan diri sendiri, untuk keperluan orang lain dan untuk kebutuhan sosial suatu komunitas dalam rangka meraih keridhoan Allah. ${ }^{59}$

Terdapat empat prinsip utama dalam sistem ekonomi Islam yang diisyaratkan dalam al Qur'an ${ }^{60}$ :

a. Hidup hemat dan tidak bermewah-mewah (abstain from wasteful and luxurius living), yang bermakna bahwa, tindakan ekonomi diperuntukan hanya sekedar pemenuhan kebutuhan hidup(needs) bukan pemuasan keinginan (wants). ${ }^{61}$

b. Implementasi zakat (implementation of zakat) dan mekanismenya pada tataran negara merupakan obligatory zakat system bukan voluntary zakat system. ${ }^{62}$ Selain zakat terdapat pula instrumen sejenis yang bersifat sukarela (voluntary) yaitu infak, shadaqah, wakaf, dan hadiah.

c. Penghapusan Riba (prohibition of riba); menjadikan system bagi hasil (profit-loss sharing) dengan instrumen mudharabah dan

${ }^{57}$ Produks adalah bagaimana komoditas yang dibutuhkan itu dihasilkan untuk memperoleh kebaahagiaan. P3EI, h. 10

${ }^{58}$ Konsumsi adalah komoditas apa yang dibutuhkan untuk memperoleh kebahagiaan. Ibid. h. 9

${ }^{59}$ Quraish Shihab, Tafsir Al-Mishbah ,V. I. h. 93.

${ }^{60}$ Mursal, "Implementasi Prinsip-prinsip Ekonomi Syariah: Alternatif Mewujudkan Kesejahteraan Berkelanjutan”, Jurnal Perspektif Ekonomi Darusalam, vol. 1 no.2, (2015):75-84.

${ }^{61}$ Q.s. 25 (al-Furqān): 67

${ }^{62}$ Q.S. 9 (at-Taubah):103 
musyarakah sebagai pengganti sistem kredit (credit system) termasuk bunga (interest rate). ${ }^{63}$

d. Menjalankan usaha-usaha yang halal (permissible conduct), jauh dari maisir dan gharar; meliputi bahan baku, proses produksi, manajemen, out put produksi hingga proses distribusi dan konsumsi harus dalam kerangka halal. ${ }^{64}$

Dari empat prinsip demikian, terlihat model perilaku muslim dalam menyikapi harta. Harta bukanlah tujuan, ia hanya sekedar alat untuk menumpuk pahala demi tercapainya falah (kebahagiaan dunia dan akhirat). ${ }^{65}$ Harta merupakan pokok kehidupan (an-Nisa (4) : 5) yang merupakan karunia Allah (an-Nisa (4): 32. Islam memandang segala yang ada di atas bumi dan seisinya adalah milik Allah SWT, sehingga apa yang dimiliki manusia hanyalah amanah. Dengan nilai amanah itulah manusia dituntut untuk menyikapi harta benda untuk mendapatkannya dengan cara yang benar, proses yang benar dan pengelolaan dan pengembangan yang benar pula. ${ }^{66}$

Sebaliknya dalam perspektif konvensional, harta merupakan asset yang menjadi hak pribadi. Sepanjang kepemilikan harta tidak melanggar hukum atau undang-undang, maka harta menjadi hak penuh si pemiliknya. Dengan demikian perbedaan Islam dan konvensional tentang harta, terletak pada perbedaan cara pandang. Islam cenderung melihat harta berdasarkan flow concept sedangkan konvensional memandangnya berdasarkan stock concept.

Harta, dimasukan dalam pembahasan uang dan kapital. Menurutnya uang dalam Islam adalah public goods yang bersifat flow concept sedangkan kapital merupakan private goods yang bersifat stock concept. Sementara itu menurut konvensional uang dan kapital merupakan private goods ${ }^{67}$. Namun pada tingkatan praktis, perilaku ekonomi (economic behavior) sangat ditentukan oleh tingkat

${ }^{63}$ Q.S. 2 (al-Baqarah): 275

${ }^{64}$ Q.S. 7(al-A $\left.r \bar{a}\right)$ ): 157

${ }^{65}$ Q.S. 28 (al-Qashāsh): 77

${ }^{66}$ Q.S. 33 (al-Ahzāb): 72

${ }^{67}$ Lihat Adiwarman Azwar Karim, Ekonomi Islam: Suatu Kajian Ekonomi Makro, The International Institute of Islamic Thought Indonesia (IIIT Indonesia), 2002, hlm. 19 22. 
keyakinan atau keimanan seseorang atau sekelompok orang yang kemudian membentuk kecenderungan prilaku konsumsi dan produksi di pasar. Dengan demikian dapat disimpulkan tiga karakteristik perilaku ekonomi dengan menggunakan tingkat keimanan sebagai asumsi:

a. Ketika keimanan ada pada tingkat yang cukup baik, maka motif berkonsumsi atau berproduksi akan didominasi oleh tiga motif utama tadi; mashlahah, kebutuhan dan kewajiban.

b. Ketika keimanan ada pada tingkat yang kurang baik, maka motifnya tidak didominasi hanya oleh tiga hal tadi tapi juga kemudian akan dipengaruhi secara signifikan oleh ego, rasionalisme (materialisme) dan keinginan-keinganan yang bersifat individualistis.

c. Ketika keimanan ada pada tingkat yang buruk, maka motif berekonomi tentu saja akan didominasi oleh nilai-nilai individualistis (selfishness); ego, keinginan dan rasionalisme.

Demikian pula dalam konsumsi, Islam memposisikan sebagai bagian dari aktifitas ekonomi yang bertujuan mengumpulkan pahala menuju falah (kebahagiaan dunia dan akherat). Motif berkonsumsi dalam Islam pada dasarnya adalah mashlahah (public interest or general human good $)^{68}$ atas kebutuhan dan kewajiban.

Sementara itu Yusuf Qardhawi ${ }^{69}$ menyebutkan beberapa variabel moral dalam berkonsumsi, di antaranya; konsumsi atas alasan dan pada barang-barang yang baik (halal), berhemat, tidak bermewahmewah, menjauhi hutang, menjauhi kebakhilan dan kekikiran. Dengan demikian aktifitas konsumsi merupakan salah satu aktifitas ekonomi manusia yang bertujuan untuk meningkatkan ibadah dan keimanan kepada Allah SWT dalam rangka mendapatkan

68 Mashlahah secara bahasa berarti kebergunaan (utility) atau kesejahteraan (welfare), yang oleh Abu Hamid Al Ghazali (505 H/1111 M) dan Abu Ishaq Al Shatibi (790 H/1388 M) masalih (plural of Mashlahah) dibagi menjadi tiga kategori; esensial (essential/daruriyah), pelengkap (complementary/häjiyyah) dan keinginan (desirableltahsiniyyah). Dan tugas negaralah yang memastikan kemashlahatan kategori pertama dari masyarakat itu terpenuhi dengan baik. Lihat Muhammad Akram Khan, 'The Role of Government in the Economy," The American Journal of Islamic Social Sciences, Vol. 14, No. 2, 1997, p. 157.

${ }^{69}$ Yusuf Qardhawi, "Peran Nilai dan Moral dalam Perekonomian Islam," Rabbani Press, Jakarta (1995). 
kemenangan, kedamaian dan kesejahteraan akherat (falāh), baik dengan membelanjakan uang atau pendapatannya untuk keperluan dirinya maupun untuk amal shaleh bagi sesamanya.

Dalam al-Qur'an ajaran tentang konsumsi dapat diambil dari kata kulu dan isyrabu terdapat sebanyak 21 kali. Sedangkan makan dan minumlah (kulu wasyrabu) sebanyak enam kali. Jumlah ayat mengenai ajaran konsumsi, belum termasuk derivasi dari akar kata akala dan syaraba selain fi'il amar di atas sejumlah 27 kali. $^{70}$ Pada ayat-ayat tersebut secara tegas, terdapat prinsip halal dan baik, prinsip ketiadaan mengikuti hawa nafsu, prinsip syukur dan prinsip tauhid. Dengan prinsip-prinsip demikian, maka pola konsumsi seseorang dan juga masyarakat, diarahkan kepada kebutuhan dan kewajiban berdasakan standar-standar prinsip di atas.

Diyakini pula bahwa aktifitas ekonomi berawal dari kebutuhan manusia untuk terus hidup (survive) di dunia. Segala keperluan untuk bertahan untuk hidup akan sekuat tenaga diusahakan sendiri, namun ketika keperluan hidup tidak dapat dipenuhi sendiri menyebabkan adanya berbagai interaksi untuk proses pemenuhan keperluan hidup manusia. Interaksi inilah yang sebenarnya merepresentasikan interaksi permintaan dan penawaran, interaksi konsumsi dan produksi, sehingga memunculkan pasar sebagai wadah interaksi ekonomi.

Pemenuhan keperluan hidup manusia secara kualitas memiliki tahapan-tahapan pemenuhan. Berdasarkan teori Maslow, keperluan hidup berawal dari pemenuhan keperluan yang bersifat dasar (basic needs), kemudian pemenuhan keperluan hidup yang lebih tinggi kualitasnya seperti keamanan, kenyamanan dan aktualisasi. Sayang

${ }^{70}$ Diantara ayat-ayat konsumsi dalam al-Qur'an adalah Albaqarah(2): 168, 172, 187, al-Maidah(5): 4, 88, al-An'am(6) 118, 141, 142, al-A'raf(7):31, 160, 161, al-Anfal(8): 69, an Nahl (16): 114, al-Isra(17): 26-28, Toha(20): 54, 81, al-Hajj(22): 28, 36, alMukminun(23): 51, Saba(34): 15, at-Tur(52): 19, al-Mulk (67): 15, al-Haqqah(69): 24, almursalat(77): 43, 46 dan lain-lain. 
teori Maslow ini merujuk pada pola pikir individualisticmaterialistik. $^{71}$

Parameter kepuasan dalam ekonomi Islam bukan hanya terbatas pada benda-benda konkrit (materi), tapi juga tergantung pada sesuatu yang bersifat abstrak, seperti amal shaleh yang manusia perbuat. Kepuasan dapat timbul dan dirasakan oleh seorang manusia muslim ketika harapan mendapat kredit poin dari Allah SWT melalui amal shalehnya semakin besar. ${ }^{72}$

Secara fundamental prinsip keadilan ekonomi dalam al-Qur'an mengambil posisi berbeda dalam hal konsumsi dengan pendekatan ekonomi Libertarian. Perbedaannya terletak pada cara atau pendekatan dalam memenuhi kebutuhan dan keinginan manusia. Keadilan ekonomi dalam al-Qur'an tidak menghendaki dan mengakui pola konsumsi yang murni materialistik. Semakin tinggi manusia menaiki tangga peradaban, konsumsi lebih dibayang-bayangi oleh keinginan-keinginan psikologis. Selera artistik, gaya hidup snobbish (bergelimang kemewahan), dorongan untuk pamer, semua faktor psikologis ini memainkan peran yang sangat dominan dalam menentukan bentuk-bentuk lahiriah konkret dari keinginan-keinginan psikologis tersebut. ${ }^{73}$ Peradaban modern telah menghancurkan kesederhanaan; peradaban materialistik mewarnai kesenangan yang terus membuat keinginan-keinginan manusia menjadi sangat bervariasi dan banyak, dampaknya kesejahteraan ekonomi hampir hanya diukur dari berbagai karakter keinginannya itu yang diupayakan untuk dicapai melalui sarana-sarana tertentu.

Sejak awal al-Qur'an memberikan kebebasan memilih (freedom of choice) pada semua orang untuk mengonsumsi segala sesuatu yang menyenangkan dan disukai, sesuai dengan kebutuhan-kebutuhan sosial tradisional dan perbedaan temperamental mereka. Al-Qur'an hanya memberikan rambu proporsionalitas berupa perilaku tengah-

${ }^{71}$ Abdurrohman Kasdi, "Tafsir Ayat-ayat Konsumsi dan Implikasinya terhadap Pengembangan Ekonomi Islam”, Equilibrium, vol. 1 no. 1, (2013): 18-32.

${ }^{72}$ Hasan Al Banna, Risalah Pergerakan Ikhwanul Muslimin, (Intermedia, Jakarta 1997).hlm. 387-409.

73 M.A. Mannan, Islamic Economics: Theory and Practice (Delhi, Idarah-i Adabiyat-i Delli, 1980), hlm. 79. 
tengah dalam konsumsi ${ }^{74}$ - antara asketisme yang sembunyi dari kesenangan dunia di satu sisi, dan materialisme yang membenamkan manusia dalam kesenangan inderawi dan hedonisme kehidupan; tidak melampaui batas maksimal (berlebihan, boros, dan mewah) atau batas minimal (kikir dan bakhil); keterbatasan sumber daya ekonomi (untuk memenuhi keinginan) merupakan pertimbangan utama bagi efisiensi dan prioritas (awlawiyah) dalam pemenuhan kebutuhan berdasarkan preferensi dharūriyyāt, hājiyyat, dan tahsāniyyāt. ${ }^{75}$.

Membelanjakan kekayaan untuk kebutuhan dan keinginan pribadi bukanlah hal buruk sejauh kebutuhan dan keinginan itu tidak akan membahayakan kelangsungan (sustainability) hidup dirinya dan masyarakat umumnya. Memenuhi dan memanfaatkan kebutuhan pribadi harus berada dalam kerangka dan batasan-batasan tertentu agar konsumsi atas sumber daya tidak melanggar "rambu-rambu ekologis dan kemanusiaan" dan menjamin keberlangsungan masa depan. Konsumsi tidak semata berorientasi keduniaan dan berjangka pendek, namun juga untuk memastikan kehidupan jangka panjang dengan bekerja untuk kesejahteraan ekologis dan kemanusiaan melalui suatu pengurangan dalam pemborosan dan konsumsi yang tidak penting meskipun ia memiliki kekayaan yang cukup untuk mendapatkannya.

Perilaku konsumsi harus berpijak pada prinsip keselamatan, yakni sustainability dan investasi masa depan secara kontinyu. ${ }^{76}$ Untuk itu, al-Qur'an menegaskan dalam beberapa ayatnya tentang berjuang untuk kesinambungan generasi dan masa depan, 77 kemakmuran bumi ( isti 'mār fì al-ardh) dan, sekaligus larangan melakukan kerusakan atas lingkungan ( fasad fí al-ardh).$^{78}$ Inilah yang dimaksud sebagai prinsip solidaritas kemanusiaan dan lingkungan (hifdz al-bīah).

${ }^{74}$ Q.S. 25 (al-Furqan): 67.

${ }^{75}$ Lihat al-Ghazali dalam al-Mustasyfā fì 'Ilm al-Ushūl (Beirut.: Dar al-Fikr, t.th.) dan Imam al-Shatibi dalam al-Muwāfaqāt fi Ushūl al-Ahkām, (Beirut: Dār al-Fikr, t.th.).

${ }^{76}$ QS. 59 (al-Hasyr): 18.

${ }^{77}$ QS. 4 (an-Nisā'):9.

${ }^{78}$ QS. 5 (al-Mā idah):32; lihat juga QS. 2 (al-Baqarah):251, dan 220. 
Perilaku konsumsi dalam konteks al-Qur'an mempunyai hubungan erat dengan komitmen rasional dan moral. Al-Qur'an menggarisbawahi cara memanfaatkan dan mengeluarkan kekayaan dibangun atas fondasi nilai keadilan. Ada perbedaan mendasar antara Prinsip Libertarianisme yang menjadi falsafah Kapitalisme, dan anak kandungnya Sosialisme yang mendasarkan diri pada Prinsip Egalitarianisme Radikal, dengan prinsip al-Qur'an. Perilaku konsumen menurut Kapitalisme bersumber dari "rasionalisme ekonomi" dan Prinsip Utilitarianisme (Prinsip Berbasis Kesejahteraan). Rasionalisme ekonomi menafsirkan perilaku manusia berdasarkan pada kalkulasi kaku yang diarahkan semata untuk keberhasilan ekonomi. Keberhasilan ekonomi dimaknai secara definitif sebagai menciptakan uang dari manusia. Perolehan kekayaan apakah dalam bentuk uang maupun komoditas, merupakan tujuan utama kehidupan. Sementara Prinsip Utilitarianisme berfungsi sebagai sumber nilai-nilai dan sikap moralnya.

\section{E. KESIMPULAN}

Islam mengajarkan bahwa dalam memproduksi, mendistribusikan dan menkonsumsi dilakukan secara seimbang, adil dan berkesinambungan. Membelanjakan kekayaan untuk kebutuhan dan keinginan pribadi bukanlah hal buruk sejauh kebutuhan dan keinginan itu tidak akan membahayakan kelangsungan (sustainability) hidup dirinya dan masyarakat umumnya. Memenuhi dan memanfaatkan kebutuhan pribadi harus berada dalam kerangka dan batasan-batasan tertentu agar konsumsi atas sumber daya tidak melanggar "rambu-rambu ekologis dan kemanusiaan" serta menjamin keberlangsungan masa depan. Konsumsi diatur untuk memastikan kehidupan jangka panjang dengan bekerja untuk kesejahteraan ekologis dan kemanusiaan. Perilaku konsumsi harus berpijak pada prinsip keselamatan, yakni sustainability dan investasi masa depan secara kontinyu. Untuk itu, masyarakat berkewajiban berjuang untuk kesinambungan generasi dan masa depan, kemakmuran bumi ('isti 'mar fi al-ardh) dan sekaligus larangan melakukan kerusakan atas lingkungan (fasad fi al-ardh, 'ayth fi al-ardh). Inilah yang dimaksud sebagai prinsip solidaritas kemanusiaan dan lingkungan (hifdz al-bi`ah). 


\section{DAFTAR PUSTAKA}

Abdul Hamid Al-Ghazali. Pilar-Pilar Kebangkitan Umat. Jakarta: AlI tisham Cahaya Utama. 2001.

Abdul Wahhab Khalaf. Ylm ushūl al-fiqh. Dār ar-Rasyìd. tt. tp. 2008.

Abdurrahman Al-Maliki. Politik Ekonomi Islam, alih bahasa: Ibnu Sholah Bangil : Al-Izzah. 2001.

Abdurrohman Kasdi, "Tafsir Ayat-ayat Konsumsi dan Implikasinya terhadap Pengembangan Ekonomi Islam”, Equilibrium, vol. 1 no. 1, 2013, hal. 18-32.

Abu Dawud, Sunan Abu Dawud (Bandung: Dahlan. T.th.), J. 4

Adiwarman A. Karim, Ekonomi Mikro Islami, Jakarta: Raja Grafindo Persada. 2010. ed. 3

Adiwarman A. Karim. Ekonomi Islam: suatu kajian kontemporer. Jakarta: Gema Insani Press. tt.

Adnan Harahap dkk. Islam Dan Lingkungan Hidup. Jakarta: Yayasan Swarna Bhumy. 1997.

Afzalur Rahman. Doktrin Ekonomi Islam. J. 3, cet. 2. Yogyakarta: Dana Bakti Wakaf. 2002.

Ahmad. Al-Qur'an: Kemiskinan dan Pemerataan Pendapatan. Yogyakarta: Dana Bhakti Prima Yasa. 1998.

Al-Bukhari, Shahih al-Bukhari Bukhary, Juz I. Bandung: Dahlan. Tth.

Al-Ghazali. al-Mustasyfa fi 'Ilm al-Usul. Beirut: Dar al-Fikr, t.th.

Al-Maliki, Abdurrahman. Politik Ekonomi Islam, alih bahasa: Ibnu Sholah. Bangil : Al-Izzah. 2001.

Anwar Abbas. Bung Hatta dan Ekonomi Islam. Jakarta: Kompas. 2010

Boediono. Ekonomi Indonesia mau kemana?, ed. Ke 3. Jakarta: PT. Gramesia. 2010.

Deliar Noer. Islam dan Masyarakat. Jakarta: Yayasan Risalah. 2003.

Depag RI. Al Quran dan Terjemahannya. Bandung: Diponegoro. 2006.

Dieb al-Buga dan Syaikh Muhyiddin Mistu, al-Wafi, terj. Iman Sulaiman. Pustaka Al-Kautsar. 2009.

Fauzi, A. Ekonomi Sumber Daya Alam dan Lingkungan. Jakarta : PT. Gramedia Pustaka Utama. 2004. 
Green Peace. "Kegiatan Ilegal Perusakan Hutan dan Lahan Gambut: Sinar Mas - apa yang telah kalian lakukan?”. London. Laporan. December 2009.

Harian Kompas. "Serap 1 Juta Pekerja Baru”. Jakarta. 4 Januari 2010.

Hasan Al Banna. Risalah Pergerakan Ikhwanul Muslimin. Jakarta : Intermedia 1997.

http://agustianto.niriah.com/2008/10/04/etika-produksi-dalam-islam/. diakses 3 Maret 2012.

http://tanbihun.com/kajian/analisis/prinsip-prinsip-ekonomi-islam/ Januari 2012.

Husaini, S. Waqar Ahmed. Islamic Sciences. New Delhi : Goodwork Book. 2002.

Ibn Hajar al-Asqalani, Fath al-Bari Syarh Sahih al-Bukhari vol. V. Beirut: Dar al-Mu`arrafah, t.th.

Imam al-Shatibi, al-Muwafaqat fi Us\}ul al-Ahkam. Beirut: Dar al-Fikr, t.th.

Imam Bukhari, Shahih al-Bukhari, (T.T. Dar al-Ihya al-Kutub al-`Arabiyyah. T.th.

Imam Muslim, Shahih Muslim, (Terj.) J. II,Jakarta: Widjaya, bekerjasama dengan CV. Wicaksana Semarang.

Iqbal Hasan. Pokok-Pokok Materi Metodologi Penelitian dan Aplikasinya. Jakarta: Gralia Indonesia. 2002.

Jalaluddin Al-Mahalli dan Jalaluddin as-Susuthi, Tafsir Jalalain, T.t. : Dar al-ilm. T.th., Juz I,

Jimli Assiddiqie. Konstitusi Ekonomi. Jakarta: Penerbit Buku Kompas. 2010.

Johan Iskandar. Ekologi Manusia dan Pembangunan Berkelanjutan. Bandung: Program Studi. 2009.

Juhari, Juhari; Masdar, Masdar. Konsep Kepemilikan dan Usaha Dalam Islam. Al-Insyiroh: Jurnal Studi Keislaman, 2015, 1.1: 44-69.

Karl Marx dan Friedriech Engel. Capital: Manifesto of the Communist Party. Chicago: Encyclopaedia of Britannica Inc. 1952.

M. Quraish Shihab. Membumikan Al-Quran. Bandung: Mizan. 1999. -, Tafsir Al-Mishbah, Jakarta: Lentera hati. 2002, Vol. 1 -, Tafsir Al-Mishbah, Jakarta: Lentera hati. 2002, Vol. 5

M. Quraish Shihab. Tafsir Al-Mishbah Vol. 5. Jakarta: Lentera hati. 2002.

M. A. Mannan. Islamic Economics: Theory and Practice. Delhi: Idarah-i Adabiyat-i Delli. 1980. 
Muhammad Akram Khan. 'The Role of Government in the Economy," The American Journal of Islamic Social Sciences.

Muhammad Ali Ash-Shabuni, Shafwāt at-Tafāsir. Jil. I, Beirut. Dār al-Fikr. 1976

Muhammad Syafi'i Antonio. Bisnis Dan Kewirausahaan (Ensiklopedi Leadership Dan Manajemen Rasulullah Saw). Jakarta: Tazkia Publishing. 2010.

Muhammad, Ekonomi Islam;Kontribusi fundamentalisme Islam terhadap Ekonomi Islam. Malang: Empat Dua. 2009.

Munasinahe, M. Environmental Economics and Sustainable Development

Environment Paper No.3. The World Bank, Washington, D.C.: tp. 1993.

Mursal, "Implementasi Prinsip-prinsip Ekonomi Syariah: Alternatif Mewujudkan Kesejahteraan Berkelanjutan”, Jurnal Perspektif Ekonomi Darusalam, vol. 1 no.2, 2015, hal. 75-84.

Nawab Haider Naqvi, Syed. Ethics and Economics An Islamic Synthesis. London: The Islamic Foundation. 1981

Pusat Pengkajian Dan Pengembangan Ekonomi Islam. Ekonomi Islam. Jakarta: PT. Rajagrafindo Persada. 2008.

Sadono Sukirno, Pengantar Teori Mikroekonomi, Rajawali Press Jakarta, 2002.

Sarosa, Wicaksono \& Mulya Amri. (2008). CSR for Better Life : Indonesian Context : CSR untuk

Sayyid Quthb. Fi Zhilalil Quran, terj. As`ad Yasin dkk. Jakarta: Gema Insani Press. 2000.

Soeharsono Sagir. Ekonomi Berpihak kepada Rakyat; Pro Poor, Pro Job, Pro Growth. Bandung:AIPI. 2011.

Sugiyono. Metode Penelitian Kuantitatif, kualitatif dan $R \& D$. Bandung: Alfabeta. 2006

Suharsimi arikunto. Prosedur Penelitian Suatu Pendekatan Praktek, ed. Revisi, cet. 12. Jakarta: Rineka Cipta. 2002.

Sukada, Sony dkk. CSR for Better Life : Indonesian Context : Membumikan Bisnis. Ttp : tp 2007

Suparyanto, Didik. Prospek Perbankan Syariah di Indonesia. Al-Insyiroh: Jurnal Studi Keislaman, 2018, 2.2: 170-181. 
Syeikh Said Abdul Azhim. Keagungan Mukjizat Nabi Muhammad saw. Depok: Qulltum Media. 2006.

Taqyuddin An-Nabhani. Membangun Sistem Ekonomi Alternatif Perspektif Islam. Surabaya: Risalah Gusti. 2002.

—. Nizham Al-Islam. Tanpa Tempat Penerbit : Mansyurat Hizb AlTahrir. 2001.

. An-Nizham Al-Iqtishadi fi Al-Islam.. terj. Moch. Maghffur wahid. Surabya: Risalah Gusti. 1996

Thalhah, Hisham dkk. Ensiklopedia Mukjizat Al Quran dan Hadis Jil. 6. Jakarta: Sapta Sentosa. 2008.

Yusuf Qardaw. Hukum Zakat, cet. 5. Bandung: Mizan. 1998.

---------, Norma dan Etika Ekonomi Islam, alih bahasa: Zainal Arifin, Lc dan Dra. Dahlia Husin. Jakarta: Gema Insani Press. 2001.

......... "Peran Nilai dan Moral dalam Perekonomian Islam,". Jakarta : Rabbani Press. 1995.

. Norma dan Etika Ekonomi Islam, alih bahasa: Zainal Arifin, Lc dan

Dra. Dahlia Husin. Jakarta: Gema Insani Press. 2001. 